\title{
Cigarette smoking and non-fatal myocardial infarction in women: is the relation independent of coronary artery disease?
}

\author{
DAVID S FREEDMAN, „ף HARVEY W GRUCHOW, „ JOHN A WALKER, $\dagger$ \\ STEVEN J JACOBSEN, * ALFRED J ANDERSON, $\ddagger$ KATHLEEN A SOBOCINSKI, * \\ JOSEPH J BARBORIAK§\|
}

From the ${ }^{\star}$ Division of Biostatistics and Clinical Epidemiology, and §Department of Pharmacology and Toxicology, Medical College of Wisconsin; and †Cardiology Section, and $¥$ Cardiovascular Disease Data Registry, St Luke's Hospital; and $\mid$ Milwaukee Veterans Administration Medical Center, Milwaukee, Wisconsin, USA

SUMMARY The relation of cigarette smoking to both coronary disease and non-fatal myocardial infarction was examined in a cross sectional study of 1053 women who underwent coronary arteriography. As compared with the $\mathbf{4 8 9}$ women who had never smoked cigarettes, ever-smokers (mean duration of smoking, 25 years) were 1.6 times as likely to have significant stenotic disease and were 1.9 times as likely to have suffered a myocardial infarction. These associations were strongest in women under 50 years of age, with odds ratios of 3.5 for coronary artery disease and 4.5 for myocardial infarction. Although the extent of stenotic disease and prior myocardial infarction were strongly associated, women who smoked cigarettes remained at increased risk of a myocardial infarction even after their increased coronary artery disease had been taken into account. For example, heavy smokers ( $>30$ pack-years) were 2.3 times as likely to have had a myocardial infarction as were non-smokers; controlling for the extent of stenotic disease (in addition to age and other risk factors) reduced the estimated relative risk to only 1.9. Stratified analyses showed that this increased risk for clinical disease among smokers was evident at all levels of occlusion, even among women with minimal stenotic disease. These results, collected at the time of arteriography, suggest that non-atherogenic mechanisms may be important in the aetiology of myocardial infarction among women who smoke cigarettes.

Cigarette smoking is widely recognised as an important risk factor for coronary heart disease in men, with the risk of myocardial infarction and sudden death increasing with the number of cigarettes smoked daily. ${ }^{12}$ Recent case-control ${ }^{34}$ and cohort ${ }^{5-7}$ studies have also reported an increased risk of coronary heart disease among female smokers. In general, women who smoke cigarettes are two to four times as likely to develop clinical disease as are nonsmokers, with younger women and those smoking

Requests for reprints to Dr Joseph J Barboriak, Milwaukee Veterans Administration Medical Center, Milwaukee, WI 53295, USA.

IPresent address: Centers for Disease Control, F-16, 1600 Clifton Road, Atlanta, GA 30333, USA.

Accepted for publication 14 June 1989 more than one pack daily showing the greatest increase in risk. ${ }^{347}$

It is uncertain, however, whether the excess coronary heart disease among smokers is caused by more extensive coronary atherosclerosis. Although cigarette smokers have an atherogenic lipoprotein profile, their increased mortality from cardiovascular disease is independent of lipid concentrations. ${ }^{8}$ In addition, smokers do not consistently show increased coronary atherosclerosis upon pathological examination, ${ }^{9}$ and there is a high prevalence of cigarette smoking among patients who have clinical evidence of a myocardial infarction but unobstructed coronary arteries. $^{1011}$ Therefore, non-atherogenic mechanisms, such as nicotine and carboxyhaemoglobin, ${ }^{12}$ fibrinogen, ${ }^{1314}$ or white blood cells, ${ }^{15}$ may be involved in the aetiology of cardiovascular disease among smokers. 
Because it gives information on both coronary artery disease and previous non-fatal myocardial infarction, coronary arteriography provides a unique opportunity to assess the importance of occlusive disease and non-atherogenic factors in the development of coronary heart disease. ${ }^{16}$ For example, we have shown that even after controlling for the extent of coronary occlusion, "heavy" cigarette smoking doubles the risk for non-fatal myocardial infarction among men, ${ }^{17}$ suggesting that smoking may be involved in the precipitation of a myocardial infarction rather than in the development of atherosclerosis. Previous arteriography studies examining the relation of cigarette smoking to coronary artery disease have yielded conflicting results, ranging from a strong, positive association ${ }^{18}$ to a non-significant, negative relation. ${ }^{19}$

Because smoking may account for over a half of all coronary heart disease in women below the age of $55,{ }^{37}$ it is important to elucidate the possible mechanism(s) of this association. Therefore, the current study uses data collected at the time of arteriography to examine the relation of cigarette smoking to nonfatal myocardial infarction. The object was to determine whether the increased risk of myocardial infarction among female cigarette smokers is attributable to increased stenotic disease.

\section{Patients and methods}

\section{POPULATION AND DISEASE STATE}

The Milwaukee Cardiovascular Data Registry consists of patients referred to two Milwaukee hospitals (St Luke's and the Milwaukee Veterans Administration Center) for diagnostic coronary arteriography. Although selection of patients for coronary arteriography varies, ${ }^{20}$ criteria include $(a)$ unstable angina pectoris, $(b)$ moderate to severe stable angina, (c) recurrent chest pain of unknown origin, and (d) previous myocardial infarction or coronary artery bypass surgery. The present analyses are restricted to a subset of the 1627 white women who underwent arteriography between 1972 and 1986, and for whom concentrations of total cholesterol and triglycerides were measured. Other races represented $<5 \%(n=$ 95) of all female patients and were therefore excluded.

The extent of obstructive disease was evaluated, without knowledge of risk factor data, by a radiologist and cardiologist experienced in the interpretation of arteriograms. Although the reproducibility of these readings was not assessed, the degree of observer variability ${ }^{21}$ and disagreement with postmortem pathology findings ${ }^{22}$ is known to be moderate.

Reductions in lumen diameter caused by the most severe stenosis in the left main, left anterior descending, circumflex, and right coronary arteries were estimated, and results were incorporated into an occlusion score reflecting the overall severity of coronary artery disease. As previously reported ${ }^{17} 23$ a scale suggested by Rowe et $a^{24}$ was inverted, with 0 representing "no observed narrowing of any artery," and a score of 300 indicating "total occlusion of the major vessels." (The mean occlusion score was 77.) The number of diseased vessels was also recorded: a $\geqslant 75 \%$ narrowing of the left anterior descending, circumflex, and right coronary arteries was regarded as clinically important.

\section{INFORMATION ON RISK FACTORS}

Medical records and questionnaires were used to obtain data before arteriography on smoking history, weight, height, alcohol consumption, medication use; and histories of hypertension, angina, diabetes mellitus, and previous myocardial infarction. Women were excluded from the analyses if they reported use of thyroid or cholesterol-lowering medication, oral contraceptives, sex hormones, or had hypothyroidism or hyperthyroidism. These restrictions eliminated 558 patients, with use of sex hormones accounting for the largest category ( $n=$ 265) of exclusions. For the remaining 1069 (1627-558) women, reported intake of beer, wine, and mixed drinks was converted to $\mathrm{ml}$ of absolute alcohol per week. The body mass index $\left(\mathrm{kg} / \mathrm{m}^{2}\right)$ was used as an estimate of obesity for each woman.

After an overnight fast, blood samples were collected before arteriography. Plasma concentrations of total cholesterol and triglycerides were measured by automated procedure ${ }^{25-27}$ in a laboratory that has been standardised (and is monitored) by the Centers for Disease Control. Concentrations of high density lipoprotein cholesterol were first measured in 1977; 261 women had recorded concentrations of this lipoprotein fraction.

\section{CIGARETTE SMOKING}

The cigarette smoking category (current/past/never) of 1053 women could be determined through questionnaire. Past $(n=374)$ and current $(n=190)$ smokers showed similar levels of $(a)$ most risk factors, (b) coronary artery disease, and (c) the prevalence of prior myocardial infarction. Because many of the exsmokers were likely to have stopped smoking after a myocardial infarction (the year of stopping was not known), most analyses contrasted ever-smokers with never-smokers. (Certain analyses, however, separated the ever-smokers into past and current smokers.) Data on the duration (years) of cigarette smoking and the approximate number of cigarettes smoked daily $(<5,10,20,30$, or $>40)$ were available 
Smoking and myocardial infarction in women

for 521 of the 564 women who reported that they had ever smoked. These data were used to calculate packyears by multiplying the usual number of packs smoked daily by the number of years of smoking. Of women who reported that they had ever smoked, the median Juration of smoking was 26 years; $84 \%$ had smoked for $>10$ years.

\section{HISTORY OF NON-FATAL MYOCARDIAL}

INFARCTION

A history of myocardial infarction for each patient was also obtained through a questionnaire administered before catheterisation. The specific question was, "Has your doctor ever said that you have had a heart attack?"; $334(32 \%)$ women reported that they had suffered a heart attack.

The accuracy of these responses was not validated for these women, and false positive and false negative responses were probably reported ${ }^{28}{ }^{29}$ None the less, a previous study from the Milwaukee Cardiovascular Data Registry found that $93 \%$ of self-reported myocardial infarctions among 465 men who underwent a coronary bypass operation were confirmed by data in their medical records. ${ }^{17}$

\section{STATISTICAL ANALYSES}

Mean values of cigarette smoking and other risk factors were first contrasted according to the myocardial infarction state and the number of diseased vessels $(0 v \geqslant 1)$. The relation of cigarette smoking to both stenotic disease and myocardial infarction was then assessed in three age groups $(<50,50-59$, and $\geqslant 60$ years), and odds ratios were calculated as estimates of relative risk. The relative importance of smoking duration versus daily consumption in the relation of smoking to myocardial infarction was evaluated by logistic regression with indicator variables representing three levels of each exposure variable.

We then examined the independent relation of cigarette smoking to myocardial infarction by controlling for the extent of coronary artery disease. The occlusion score was categorised into five groups, and the association between smoking and myocardial infarction was examined within each stratum. Results were summarised over the strata using Mantel-Haenszel odds ratios, and the Mantel extension was used to test for a trend. ${ }^{30}$

The relation of pack-years (number of packs smoked per day $x$ duration of smoking) to myocardial infarction was then assessed by logistic regression. Predictor variables in the various models included: ( $a$ ) pack-years only; (b) pack-years and the occlusion score; and (c) pack-years, occlusion, and other risk factors. (The extent of coronary artery disease was treated as a risk factor for myocardial infarction in these last two models.) To avoid assumptions about the shape of the association between pack-years and myocardial infarction, ${ }^{31}$ dummy variables (representing categories of pack-years) were used in these analyses. ${ }^{32}$ Logistic regression models were also used to assess possible differences in the relation of cigarette smoking to myocardial infarction between past and current smokers.

\section{Results}

Mean values of several characteristics were first examined according to reported smoking state (never/past/current) before arteriography (data not shown). Despite a higher prevalence of hypertension among women who had never smoked, non-fatal myocardial infarctions were more common among both ex-smokers and current smokers, with estimated relative risks of $2 \cdot 1$ and $1 \cdot 6$, respectively. In addition, mean occlusion scores were approximately 25 points higher among both ex-smokers and current smokers than among women who had never smoked. Current (but not past) smokers also had slightly lower values of body mass index than did women who had never smoked $\left(25.1 v 26.2 \mathrm{~kg} / \mathrm{m}^{2}\right)$ and both current and past smokers had raised concentrations of triglycerides $(1.81$ and $1.90 v 1.67 \mathrm{mmol} / \mathrm{l})(161$ and $168 v 148 \mathrm{mg} / \mathrm{dl}$ ) and alcohol intake (69 and $118 v$ $44 \mathrm{ml} /$ week). Because past and current smokers showed similar (a) risk factor values, $(b)$ amounts of coronary artery disease, and (c) risk of previous myocardial infarction, most analyses contrasted ever-smokers $(n=564)$ with never-smokers $(n=$ 489).

We then examined differences in risk factor values according to non-fatal myocardial infarction and clinically important occlusive disease (table 1). The two variables were strongly related: the mean occlusion score was approximately twice as large (117 $v$ 58) among women who reported a myocardial infarction as in other patients. In general, however, risk factors were more strongly related to coronary artery disease. For example, concentrations of total cholesterol were $0.7 \mathrm{mmol} / 1$ (27 $\mathrm{mg} / \mathrm{dl})$ higher in women with occlusive disease than in those with no diseased vessels, but the difference between those with and those without a history of myocardial infarction was only $0.2 \mathrm{mmol} / \mathrm{l}(6 \mathrm{mg} / \mathrm{dl})$. Smoking state (ever $v$ never), triglyceride concentrations, hypertension, and diabetes were the only characteristics significantly related to both coronary artery disease and myocardial infarction.

Women who had smoked cigarettes had a higher mean occlusion score than non-smokers (91 for exsmokers, 79 for current smokers, 65 for neversmokers) and were 1.6 (current) to $2 \cdot 1$ (past) times as 
Table 1 Mean (SD) values of selected variables in women according to previous myocardial infarction and coronary artery disease

\begin{tabular}{|c|c|c|c|c|c|c|c|c|}
\hline \multirow[b]{3}{*}{$\begin{array}{l}\text { Occlusion score } \\
\text { Age (years) }\end{array}$} & \multicolumn{4}{|c|}{ Previous myocardial infarction } & \multicolumn{4}{|c|}{ Number of diseased vessels $†$} \\
\hline & \multicolumn{2}{|c|}{ No $(n=719)$} & \multicolumn{2}{|c|}{ Yes $(n=334)$} & \multicolumn{2}{|c|}{$0(n=634)$} & \multicolumn{2}{|c|}{$\geqslant 1(n=419)$} \\
\hline & $\begin{array}{l}58 \\
56\end{array}$ & $\begin{array}{l}(80)^{\star \star} \\
(10)\end{array}$ & $\begin{array}{r}117 \\
57\end{array}$ & $\begin{array}{c}(87)^{\star \star} \\
(9)\end{array}$ & $\begin{array}{l}17 \\
55\end{array}$ & $\begin{array}{l}(35)^{\star \star} \\
(11)^{\star \star}\end{array}$ & $\begin{array}{r}169 \\
58\end{array}$ & $\begin{array}{c}(57)^{\star \star} \\
(9)^{\star \star}\end{array}$ \\
\hline $\begin{array}{l}\text { Ever-smoked }(\%) \\
\% \text { smoking } \geqslant 30 \text { years } \ddagger \\
\% \text { smoking }>1 \text { pack per day } \ddagger\end{array}$ & $\begin{array}{l}49 \star \star \\
44 \\
24\end{array}$ & & $\begin{array}{l}64^{\star} \\
49 \\
28\end{array}$ & & $\begin{array}{l}49^{\star \star} \\
38^{\star \star} \\
22\end{array}$ & & $\begin{array}{l}61^{\star \star} \\
54^{\star \star} \\
30\end{array}$ & \\
\hline $\begin{array}{l}\text { Total cholesterol }(\mathrm{mmol} / \mathrm{l}) \\
\text { Triglycerides }(\mathrm{mmol} / \mathrm{l}) \\
\text { HDL cholesterol }(\mathrm{mmol} / \mathrm{l}) \S \\
\text { Body mass index }\left(\mathrm{kg} / \mathrm{m}^{2}\right) \\
\text { Alcohol intake }(\mathrm{ml} / \mathrm{wk})\end{array}$ & $\begin{array}{r}6 \cdot 0 \\
1.7 \\
1.2 \\
26 \cdot 0 \\
68\end{array}$ & $\begin{array}{l}(1 \cdot 3) \\
(1 \cdot 1)^{\star \star} \\
(0 \cdot 4) \\
(5 \cdot 2) \\
(139)\end{array}$ & $\begin{array}{l}6 \cdot 2 \\
2 \cdot \\
1 \cdot \\
26 \\
54\end{array}$ & $\begin{array}{l}(1 \cdot 3) \\
(1 \cdot 1)^{\star \star} \\
(0 \cdot 3) \\
(4 \cdot 8) \\
(90)\end{array}$ & $\begin{array}{r}5 \cdot 8 \\
1.6 \\
1 \cdot 3 \\
25 \cdot 9 \\
67\end{array}$ & $\begin{array}{l}(1 \cdot 2)^{\star \star} \\
(0.9)^{\star \star} \\
(0 \cdot 4)^{\star \star} \\
(5 \cdot 5) \\
(125)\end{array}$ & $\begin{array}{r}6 \cdot 5 \\
2 \cdot 1 \\
1 \cdot 0 \\
26 \cdot 3 \\
59\end{array}$ & $\begin{array}{l}(1 \cdot 3)^{\star \star} \\
(1 \cdot 3)^{\star \star} \\
(0 \cdot 3)^{\star \star} \\
(4 \cdot 4) \\
(128)\end{array}$ \\
\hline $\begin{array}{l}\text { History of: } \\
\text { Angina (\%) } \\
\text { Hypertension (\%) } \\
\text { Diabetes (\%) }\end{array}$ & $\begin{array}{l}60 \\
46^{\star} \\
7^{\star \star}\end{array}$ & & $\begin{array}{l}67 \\
55^{\star} \\
13^{\star}\end{array}$ & & $\begin{array}{r}56^{\star \star} \\
44^{\star \star} \\
6 \star\end{array}$ & & $\begin{array}{l}73 \star \star \\
57 \star \star \\
13 \star \star\end{array}$ & \\
\hline
\end{tabular}

HDL, high density lipoprotein.

p values compare mean concentration (or proportions) in categories of previous myocardial infarction or number of diseased vessels: ${ }^{\star} p<$ $0.01 ;{ }^{\star \star} \mathrm{p}<0.001$.

tBased on $\geqslant 75 \%$ narrowing of any vessel.

tRestricted to women who had ever smoked.

Restricted to women with recorded concentrationns of HDL cholesterol: 187 without a myocardial infarction, 74 with a myocardial infarction, 154 without coronary artery disease, and 107 with coronary artery disease.

likely to have suffered a myocardial infarction. These increased risks, however, varied with age (table 2). Among women under 50 years of age, smoking was strongly related to both coronary artery disease (odds ratios of 3.6 (past) and 3.3 (current)) and non-fatal myocardial infarction (odds ratios of 5.0 and $4 \cdot 1$ ). In contrast, all estimated risks were $\leqslant 2$ among women who were $\geqslant 50$.

Table 3 shows the relation of cigarette smoking to myocardial infarction after controlling for the extent of coronary artery disease by stratification. Although many of the cells contain small numbers, 13 of the 15 odds ratios for daily cigarette consumption were $>1$ and 11 of the odds ratios for smoking duration were $>1$. Even among women with minimal stenotic disease (occlusion score $<50$ ), the risk of myocardial infarction was increased almost twofold among women who smoked $>1$ pack daily. MantelHaenszel summary odds ratios showed that after controlling for occlusive disease, cigarette smoking remained significantly associated with myocardial infarction. Furthermore, most adjusted odds ratios were very similar to estimates that did not take the extent of coronary artery disease into account.

Table 2 Relation of cigarette smoking to coronary artery occlusion and non-fatal myocardial infarction

\begin{tabular}{|c|c|c|c|c|c|c|c|c|c|c|}
\hline \multirow{2}{*}{$\begin{array}{l}\text { Age } \\
\text { group (yr) }\end{array}$} & \multirow{2}{*}{$\begin{array}{l}\text { Smoking } \\
\text { state }\end{array}$} & \multirow[b]{2}{*}{$(N o)$} & \multicolumn{5}{|c|}{ Number of diseased vesselst } & \multicolumn{2}{|c|}{ Myocardial infarction } & \multirow{2}{*}{$\begin{array}{l}\text { Odds } \\
\text { ratio }\end{array}$} \\
\hline & & & 0 & 1 & 2 & 3 & Odds ratioł & No & Yes & \\
\hline$<50$ & $\begin{array}{l}\text { Never } \\
\text { Past } \\
\text { Current }\end{array}$ & $\begin{array}{l}(97) \\
(75) \\
(79)\end{array}$ & $\begin{array}{l}82 \\
45 \\
49\end{array}$ & $\begin{array}{r}9 \\
16 \\
20\end{array}$ & $\begin{array}{r}3 \\
10 \\
7\end{array}$ & $\begin{array}{l}3 \\
4 \\
3\end{array}$ & $\begin{array}{l}3 \cdot 6^{\star \star \star} \\
3 \cdot 3^{\star \star \star}\end{array}$ & $\begin{array}{l}85 \\
44 \\
50\end{array}$ & $\begin{array}{l}12 \\
31 \\
29\end{array}$ & $\begin{array}{l}5 \cdot 0^{\star \star \star} \\
4 \cdot 1^{\star \star \star}\end{array}$ \\
\hline $50-59$ & $\begin{array}{l}\text { Never } \\
\text { Past } \\
\text { Current }\end{array}$ & $\begin{array}{r}(176) \\
(165) \\
(63)\end{array}$ & $\begin{array}{r}127 \\
94 \\
39\end{array}$ & $\begin{array}{l}30 \\
37 \\
15\end{array}$ & $\begin{array}{r}12 \\
23 \\
6\end{array}$ & $\begin{array}{r}7 \\
11 \\
3\end{array}$ & $\begin{array}{l}2 \cdot 0^{\star \star} \\
1 \cdot 6\end{array}$ & $\begin{array}{r}131 \\
107 \\
47\end{array}$ & $\begin{array}{l}45 \\
58 \\
16\end{array}$ & $\begin{array}{l}1 \cdot 6 \\
1 \cdot 0\end{array}$ \\
\hline$\geqslant 60$ & $\begin{array}{l}\text { Never } \\
\text { Past } \\
\text { Ever }\end{array}$ & $\begin{array}{r}(216) \\
(134) \\
(48)\end{array}$ & $\begin{array}{r}116 \\
57 \\
25\end{array}$ & $\begin{array}{r}49 \\
37 \\
8\end{array}$ & $\begin{array}{l}28 \\
28 \\
10\end{array}$ & $\begin{array}{r}23 \\
12 \\
5\end{array}$ & $\begin{array}{l}1 \cdot 6^{\star} \\
1 \cdot 1\end{array}$ & $\begin{array}{r}153 \\
73 \\
29\end{array}$ & $\begin{array}{l}63 \\
61 \\
19\end{array}$ & $\begin{array}{l}1.9 \star \star \\
1.6\end{array}$ \\
\hline Overall & $\begin{array}{l}\text { Never } \\
\text { Past } \\
\text { Current }\end{array}$ & $\begin{array}{l}(489) \\
(374) \\
(190)\end{array}$ & $\begin{array}{l}325 \\
196 \\
113\end{array}$ & $\begin{array}{l}88 \\
90 \\
43\end{array}$ & $\begin{array}{l}43 \\
61 \\
23\end{array}$ & $\begin{array}{l}33 \\
27 \\
11\end{array}$ & $\begin{array}{l}1 \cdot 8^{\star \star \star} \\
1 \cdot 4^{*}\end{array}$ & $\begin{array}{l}369 \\
224 \\
126\end{array}$ & $\begin{array}{r}120 \\
150 \\
64\end{array}$ & $\begin{array}{l}2 \cdot 1^{\star \star \star} \\
1 \cdot 6^{\star}\end{array}$ \\
\hline
\end{tabular}

${ }^{\star} \mathrm{p}<0.05 ; \star \star \mathrm{p}<0.01 ;{ }^{\star \star \star \star} \mathrm{p}<0.001$.

$+75 \%$ narrowing of the left anterior descending, circumflex, or right coronary arteries.

fContrasting 0 vessel disease with $\geqslant 1$ vessel disease; the reference categories (odds ratio $=1$ ) are never-smokers. 
Table 3 Relation of cigarette smoking in women $\dagger$ to non-fatal myocardial infarction (stratified by the occlusion score)

\begin{tabular}{|c|c|c|c|c|c|c|c|c|c|c|c|c|c|c|c|c|}
\hline \multirow{3}{*}{$\begin{array}{l}\text { Myocardial } \\
\text { infarction: }\end{array}$} & \multicolumn{14}{|c|}{ Coronary artery occlusion category } & & \\
\hline & \multicolumn{2}{|c|}{$0-49$} & \multicolumn{3}{|c|}{$50-99$} & \multicolumn{3}{|c|}{$100-149$} & \multicolumn{3}{|c|}{$150-199$} & \multicolumn{3}{|c|}{$\geqslant 200$} & \multicolumn{2}{|c|}{ Summary ORs } \\
\hline & No & Yes $(O R)$ & No & $Y e$ & $(O R)$ & No & Yes & $(O R)$ & No & Yes & $(O R)$ & No & & $(\mathrm{OR})$ & $\overline{\text { Unadj }}$ & Adjust \\
\hline Non-smokers & 241 & 43 & 42 & 18 & & 35 & 11 & & 23 & 20 & & 28 & 28 & & & \\
\hline $\begin{array}{l}\text { Packs/day: } \\
\quad<1 \\
1 \\
>1\end{array}$ & $\begin{array}{l}72 \\
81 \\
35\end{array}$ & $\begin{array}{ll}14 & (1 \cdot 1) \\
18 & (1 \cdot 2) \\
12 & (1 \cdot 9)\end{array}$ & $\begin{array}{r}14 \\
6 \\
14\end{array}$ & $\begin{array}{r}13 \\
9 \\
9\end{array}$ & $\begin{array}{l}(2 \cdot 2) \\
(3 \cdot 5)^{\star} \\
(1 \cdot 5)\end{array}$ & $\begin{array}{l}11 \\
10 \\
12\end{array}$ & $\begin{array}{l}16 \\
13 \\
14\end{array}$ & $\begin{array}{l}(4 \cdot 6)^{\star \star} \\
(4 \cdot 1)^{\star \star} \\
(3 \cdot 7)^{\star}\end{array}$ & $\begin{array}{r}8 \\
13 \\
8\end{array}$ & $\begin{array}{l}10 \\
13 \\
14\end{array}$ & $\begin{array}{l}(1 \cdot 4) \\
(1 \cdot 1) \\
(2 \cdot 0)\end{array}$ & $\begin{array}{l}14 \\
15 \\
11\end{array}$ & $\begin{array}{r}14 \\
19 \\
9\end{array}$ & $\begin{array}{l}(1 \cdot 0) \\
(1 \cdot 3) \\
(0 \cdot 8)\end{array}$ & $\begin{array}{l}1 \cdot 7^{\star \star} \\
1 \cdot 8^{\star \star} \\
2 \cdot 2^{\star \star}\end{array}$ & $\begin{array}{l}1 \cdot 6^{\star} \\
1 \cdot 6^{\star} \\
1 \cdot 8^{\star \star}\end{array}$ \\
\hline $\begin{array}{l}\text { Duration (years): } \\
\quad 1-20 \\
20-29 \\
\geqslant 30\end{array}$ & $\begin{array}{l}47 \\
50 \\
64\end{array}$ & $\begin{aligned} 19 & (1.4) \\
8 & (0.9) \\
17 & (1.5)\end{aligned}$ & $\begin{array}{r}14 \\
4 \\
16\end{array}$ & $\begin{array}{r}6 \\
10 \\
15\end{array}$ & $\begin{array}{l}(1 \cdot 0) \\
(5 \cdot 8)^{\star \star} \\
(2 \cdot 2)\end{array}$ & $\begin{array}{r}4 \\
11 \\
18\end{array}$ & $\begin{array}{r}4 \\
12 \\
27\end{array}$ & $\begin{array}{l}(3 \cdot 2) \\
(3 \cdot 5)^{\star} \\
(4 \cdot 8)^{\star \star}\end{array}$ & $\begin{array}{r}6 \\
8 \\
15\end{array}$ & $\begin{array}{r}5 \\
14 \\
18\end{array}$ & $\begin{array}{l}(1 \cdot 0) \\
(2 \cdot 0) \\
(1 \cdot 4)\end{array}$ & $\begin{array}{r}6 \\
6 \\
28\end{array}$ & $\begin{array}{l}12 \\
10 \\
20\end{array}$ & $\begin{array}{l}(2 \cdot 0) \\
(1.7) \\
(0.7)\end{array}$ & $\begin{array}{l}1 \cdot 4 \\
2 \cdot 1^{\star \star} \\
2 \cdot 1^{\star \star}\end{array}$ & $\begin{array}{l}1.5 \\
1.9^{\star \star} \\
1.6^{\star \star}\end{array}$ \\
\hline
\end{tabular}

OR, odds ratio.

Stratum-specific $\mathrm{p}$ values were computed by Fisher's exact test. The overall association was tested by the summary odds ratio.

${ }^{\star} \mathrm{p}<0.05 ;{ }^{\star \star} \mathrm{p}<0.01$.

TRestricted to 489 never-smokers and 521 smokers who reported both frequency and duration of smoking.

†Mantel-Haenszel summary odds ratio.

However, the association between smoking and myocardial infarction decreased from $2 \cdot 1$ to 1.6 among women who had smoked for more than 30 years.

We assessed the relative importance of smoking duration and daily consumption of cigarettes among ever-smokers (table 4). Among these women, the estimated risk of myocardial infarction tended to be more strongly related to daily consumption (with odds ratios increasing from 1.6 to 2.4 ) than to duration (1.1 to 1.5$)$. Because a small independent effect of duration on myocardial infarction risk was seen, however, daily consumption and duration were combined to form pack-years in subsequent analyses.

Table 5 shows the relation of pack-years to myocardial infarction in three logistic regression models. Model 1 , which contains only indicator variables that represent the three categories of pack-years, shows

Table 4 Cross classification of risk of myocardial infarction in women by duration and amount of smoking

\begin{tabular}{|c|c|c|c|c|}
\hline \multirow{2}{*}{$\begin{array}{l}\text { Smoking } \\
\text { duration } \\
(y r)\end{array}$} & \multicolumn{3}{|c|}{ Number of packs smoked daily } & \multirow{2}{*}{$\begin{array}{l}\text { Adjusted } \\
\text { odds } \\
\text { ratio }\end{array}$} \\
\hline & $<1$ & 1 & $>1$ & \\
\hline $1-19$ & $\begin{array}{l}1 \cdot 3 \ddagger \\
(80)\end{array}$ & $\begin{array}{r}1.6 \\
(46)\end{array}$ & $\begin{array}{r}2.5 \\
(24)\end{array}$ & $1 \cdot 1$ \\
\hline $20-29$ & $\begin{array}{r}2 \cdot 1 \\
(43)\end{array}$ & $\begin{array}{l}1.8 \\
(53)\end{array}$ & $\begin{array}{r}4.5 \\
(37)\end{array}$ & $1 \cdot 7$ \\
\hline$\geqslant 30$ & $\begin{array}{r}2.4 \\
(63)\end{array}$ & $\begin{array}{r}2 \cdot 0 \\
(98)\end{array}$ & $\begin{array}{r}2 \cdot 6 \\
(77)\end{array}$ & $1 \cdot 5$ \\
\hline $\begin{array}{l}\text { Adjusted odds } \\
\text { ratio }+\end{array}$ & $1 \cdot 6$ & 1.5 & $2 \cdot 4$ & \\
\hline
\end{tabular}

^Restricted to women who had ever smoked.

tAdjusted levels for each duration or frequency category.

Estimated risk of myocardial infarction relative to non-smokers. Values have been adjusted by logistic regression for age, total cholesterol, triglycerides, alcohol intake, body mass index, and histories of hypertension and diabetes. Sample size for durationamount category is shown in parentheses. that the estimated risk of myocardial infarction among smokers increased from 1.5 to 2.3 with increasing number of pack-years. Furthermore, with the exception of women who had been smoking for $\geqslant 30$ pack-years, these associations were unaffected by controlling for the extent of stenotic disease (model 2). (Including the extent of stenotic disease as an independent variable, however, greatly improved the prediction of myocardial infarction.) Furthermore, the effect of cigarette smoking was also independent of other risk factors (model 3). The joint contribution of eight additional risk factors in predicting myocardial infarction was only marginally significant $(p=0 \cdot 11)$.

Additional regression models that included indicator variables representing (a) past $v$ never smokers, and (b) current $v$ never smokers, were then constructed to assess possible differences among ever-smokers (data not shown). Results indicated that controlling for the extent of coronary artery occlusion reduced the unadjusted odds ratios from 2.1 to 1.9 among ex-smokers and did not alter the odds ratio of 1.6 among current smokers.

\section{Discussion}

The relative risk of cardiovascular disease among cigarette smokers compared with non-smokers varies according to the clinical entity examined: relative risks range from 1 for angina pectoris to $>10$ for sudden death. ${ }^{6}$ In addition, the excess risk of myocardial infarction among cigarette smokers drops by $50 \%$ within the first year after stopping smoking, ${ }^{33}$ and despite high rates of clinical disease, cigarette smokers have not consistently been found to have increased amounts of coronary atherosclerosis. ${ }^{34}$ Therefore, smoking may be an acute precipitant for 
Table 5 Multivariable relation ${ }^{\star}$ of pack-years to non-fatal myocardial infarction in women

\begin{tabular}{|c|c|c|c|c|c|c|}
\hline \multirow[b]{3}{*}{ Predictor variable } & \multicolumn{6}{|c|}{ Model } \\
\hline & \multicolumn{2}{|l|}{1} & \multicolumn{2}{|l|}{2} & \multicolumn{2}{|l|}{3} \\
\hline & $O R$ & $(95 \% C I)$ & $O R$ & $(95 \% C I)$ & $O R$ & $(95 \% C I)$ \\
\hline $\begin{array}{c}\text { Pack-years } \dagger: \\
\quad<15 \\
15-29 \\
\geqslant 30\end{array}$ & $\begin{array}{l}1.5 \\
1.7 \\
2.3\end{array}$ & $\begin{array}{l}(1 \cdot 0,2 \cdot 3) \\
(1 \cdot 1,2 \cdot 7) \\
(1 \cdot 6,3 \cdot 4)\end{array}$ & $\begin{array}{l}1.5 \\
1.7 \\
1.9\end{array}$ & $\begin{array}{l}(1 \cdot 0,2 \cdot 4) \\
(1 \cdot 1,2 \cdot 7) \\
(1 \cdot 3,2 \cdot 8)\end{array}$ & $\begin{array}{l}1.6 \\
1.8 \\
1.9\end{array}$ & $\begin{array}{l}(1 \cdot 0,2 \cdot 5) \\
(1 \cdot 1,2 \cdot 8) \\
(1 \cdot 3,2 \cdot 9)\end{array}$ \\
\hline $\begin{array}{l}\text { Occlusion score } \ddagger \\
\text { Other risk factors }\end{array}$ & & & 1.8 & $(1 \cdot 6,2 \cdot 1)$ & $\frac{1 \cdot 8}{-}$ & $(1 \cdot 5,2 \cdot 1)$ \\
\hline $\begin{array}{l}\text { Degrees of freedom } \\
2 \times \text { Maximised log } \\
\text { likelihood }\end{array}$ & & $\begin{array}{l}3 \\
-1036\end{array}$ & & $\begin{array}{l}4 \\
-971\end{array}$ & & $\begin{array}{l}12 \\
-958\end{array}$ \\
\hline
\end{tabular}

$\mathrm{OR}$, odds ratio; $\mathrm{CI}$, confidence interval.

„Estimated by logistic regression. Restricted to women with recorded levels of all covariates $(n=860)$.

tThe effect of each smoking category is estimated relative to non-smokers.

† Standardised odds ratio associated with a 1 standard deviation change in the predictor variable.

$\S$ Age, age ${ }^{2}$, total cholesterol, triglycerides, body mass index, alcohol intake, and histories of hypertension and diabetes.

coronary heart disease, possibly related to the development of a thrombus over an ulcerated plaque, rather than an influence on the progression of the atherosclerotic lesion. Previous case reports suggest that cigarette smoking can precipitate a myocardial infarction even among persons with minimal stenotic disease. $^{1011}$

The results of the current study, which closely accord with earlier findings of Hartz et al in men, ${ }^{17}$ document the importance of these non-atherogenic effects in women. Overall, female patients who had ever smoked cigarettes were 1.9 times as likely to have suffered a myocardial infarction as were those who had never smoked. Although cigarette smokers also had significantly more stenotic disease than did non-smokers, this accounted for little of their increased risk for myocardial infarction; controlling for the extent of occlusive disease yielded an odds ratio (ever-smokers versus never-smokers) of 1.7. Controlling for coronary artery disease, however, did reduce the risk of myocardial infarction among women who had smoked for more than 30 years (unadjusted odds ratio $=2.1 v 1.6$, adjusted). These results suggest that while the non-atherogenic effects of smoking may predominate, smoking-related increases in coronary atherosclerosis are also important in the aetiology of myocardial infarction among long term smokers.

Although female patients undergoing arteriography are not representative of all women with coronary artery disease, several of the current results accord closely with those from less selected populations. Increased concentrations of triglycerides were seen among patients who reported smoking cigarettes. In addition, as reported by others, the relation of smoking to myocardial infarction was strongest in relatively young women, ${ }^{346}$ and increased with the amount smoked daily. ${ }^{127}$ Results from the Lipid Research Clinics Follow-up Study also show that the effects of cigarette smoking on cardiovascular disease are not attributable to adverse lipid concentrations, ${ }^{8}$ and population-based studies have failed to show consistently increased coronary atherosclerosis among cigarette smokers.' Therefore, nonatherogenic mechanisms may be important in the precipitation of coronary heart disease not only among persons undergoing coronary arteriography, but also in the general population. Coronary arteriography, however, provides a unique opportunity to control for the extent of coronary atherosclerosis in assessing the stage of disease at which risk factors act.

In addition to the non-representativeness of women in the current study, however, other methodological questions should be considered in interpreting these results. Because it is cross-sectional, risk factor values may not accurately reflect values in the past, and it is possible that many of the exsmokers stopped smoking shortly before arteriography, perhaps after a myocardial infarction. (This possibility is supported by the slightly higher risk associated with past, as opposed to current, smoking state.) To minimise this misclassification, however, past and current smokers were combined in most analyses in the current study; $90 \%$ of these eversmokers had smoked for $>7$ years. In addition, the current analyses studied survivors of a myocardial infarction, and it is possible that the effects of cigarette smoking on sudden death may differ from those seen for non-fatal myocardial infarction. 
Inaccurate responses were also probably recorded for previous myocardial infarction. Although population surveys indicate that false positive responses in men may exceed $20 \%{ }^{2829}$ women who underwent coronary arteriography in the current study were likely to have been more familiar with their medical diagnoses. For example, as previously observed in the Milwaukee Cardiovascular Data Registry, only $7 \%$ of self-reported heart attacks among 465 men could not be confirmed by data in their medical records. ${ }^{17}$ Furthermore, women who reported a myocardial infarction in the current study had higher triglyceride concentrations and more extensive stenotic disease than did other women; occlusion scores were 117 and 58, respectively. Because smokers are $(a)$ less likely to survive an initial myocardial infarction, ${ }^{35}{ }^{36}$ and $(b)$ patients who had suffered a myocardial infarction might under-report their smoking habits, the importance of cigarette smoking may have been underestimated in this study.

A myocardial infarction is typically caused by a thrombosis superimposed on a stenosed vessel, and therefore, risk ractors for coronary heart disease may act either by increasing the extent of coronary artherosclerosis or by precipitating the terminal event. There are numerous mechanisms whereby smoking could influence the risk of myocardial infarction independently of occlusive disease, ${ }^{34}$ and even without increased coronary artery disease, the frequency and duration of ischaemic episodes seem to be greatly increased among smokers. ${ }^{37}$ Cigarette smokers have raised white blood cell counts, and much evidence indicates that this is a strong predictor of myocardial infarction, possibly because raised counts can obstruct small vessels or injure endothelial cells. ${ }^{15}$ Smoking also affects haemostatic and clotting factors, ${ }^{38}$ and the relation of smoking to subsequent myocardial infarction is partly mediated by increased concentrations of fibrinogen among smokers. ${ }^{14}$ Other mechanisms, including the toxic effects of carbon monoxide and nicotine ${ }^{12}$ or alterations in vessel diameter ${ }^{39}$ may be involved in the pathogenesis of myocardial infarction among cigarette smokers.

Although the specific mechanisms have not been documented, the current findings show the importance of the non-atherogenic effects of cigarette smoking in the development of myocardial infarction among women. Irrespective of the extent of coronary artery disease, cigarette smokers are at increased risk for a myocardial infarction, and other findings suggest that they could quickly reduce their excess risk by stopping smoking. ${ }^{33}$ Unfortunately, the smokers at highest risk are not stopping their habit at the same rate as are those at less risk. ${ }^{40}$ Even among women who undergo arteriography, a large proportion continue to smoke.

We acknowledge the interest and support of members of the Milwaukee Cardiovascular Data Registry.

Supported by grants from the National Institute of Health and by the Medical Research Service of the Veterans Administration.

\section{References}

1 The Pooling Project Research Group. Relationship of blood pressure, serum cholesterol, smoking habit, relative weight and ECG abnormalities to incidence of major coronary events: final report of the Pooling Project. J Chronic Dis 1978;31:201-306.

2 Neaton JD, Kuller LH, Wentworth D, Borhani NO. Total and cardiovascular mortality in relation to cigarette smoking, serum cholesterol concentration, and diastolic blood pressure among black and white males followed up for five years. Am Heart J 1984; 108:759-69.

3 Slone D, Shapiro S, Rosenberg L, et al. Relation of cigarette smoking to myocardial infarction in young women. N Engl J Med 1978;298:1273-6.

4 Rosenberg L, Shapiro S, Kaufman DW, Slone D, Miettinen O, Stolley PD. Cigarette smoking in relation to the risk of myocardial infarction in young women. Modifying influence of age and predisposing factors. Int J Epidemiol 1980;9:57-63.

5 Doll R, Gray R, Hafner B, Peto R. Mortality in relation to smoking: 22 years' observations on female British doctors. Br Med J 1980;i:967-71.

6 Kannel WB, McGee DL, Castelli WP. Latest perspectives on cigarette smoking and cardiovascular disease: the Framingham Study. J Card Rehabil 1984;4: 267-77.

7 Willett WC, Green A, Stampfer MJ, et al. Relative and absolute excess risks of coronary heart disease among women who smoke cigarettes. $N$ Engl J Med 1987; 317:1303-9.

8 Criqui MH, Cowan LD, Tyroler HA, et al. Lipoproteins as mediators for the effects of alcohol consumption and cigarette smoking on cardiovascular mortality: results from the Lipid Research Clinics Follow-up Study. Am J Epidemiol 1987;126:629-37.

9 Solberg LA, Strong JP. Risk factors and atherosclerotic lesions. A review of autopsy studies. Ateriosclerosis 1983;3:187-98.

10 Khan AH, Haywood LJ. Myocardial infarction in nine patients with radiologically patent coronary arteries. N Engl J Med 1974;291:427-31.

11 McKenna WJ, Chew CYC, Oakley CM. Myocardial infarction with normal coronary angiogram. Possible mechanism of smoking risk in coronary artery disease. Br Heart J 1980;43:493-8.

12 Aronow WS, Kaplan NM. Smoking. In: Kaplan NM, Stamler J, eds. Prevention of coronary heart disease. Practical management of the risk factors. Philadelphia: WB Saunders, 1983:51-60. 
13 Wilhelmsen L, Svärdsudd K, Korsan-Bengsten K, Larsson B, Welin L, Tibblin G. Fibrinogen as a risk factor for stroke and myocardial infarction. $N$ Engl $J$ Med 1984;311:501-5.

14 Kannel WB, D'Agostino RB, Belanger AJ. Fibrinogen, cigarette smoking, and risk of cardiovascular disease: insights from the Framingham Study. Am Heart $J$ 1987;113:1006-10.

15 Ernst E, Hammerschmidt DE, Bagge U, Matrai A, Dormandy JA. Leukocytes and the risk of ischemic diseases. JAMA 1987;257:2318-24.

16 Pearson TA. Coronary arteriography in the study of the epidemiology of coronary artery disease. Epidemiol Rev 1984;6:140-66.

17 Hartz AJ, Barboriak PN, Anderson AJ, Hoffman RG, Barboriak JJ. Smoking, coronary artery occlusion, and nonfatal myocardial infarction. JAMA 1981;246: 851-3.

18 Herbert WH. Cigarette smoking and arteriographically demonstrable coronary artery disease. Chest 1975; 67:49-52.

19 Vlietstra RE, Kronmal RA, Frye RL, Seth AK, Tristani FE, Killip T III. Factors affecting the extent and severity of coronary artery disease in patients enrolled in the Coronary Artery Surgery Study. Arteriosclerosis 1982;2:208-15.

20 Willerson JT. Selection of patients for coronary arteriography. Circulation 1985;72(suppl V):V3-8.

21 Zir LM, Miller SW, Dinssmore RE, Gilbert JP, Harthorne JW. Interobserver variability in coronary angiography. Circulation 1976;53:627-32.

22 Fisher CM. Correlation of antemortem angiography with pathology. In: Bond MG, Insull W Jr, Glagov S, Chandler AB, Cornhill JF, eds. Clinical diagnosis of atherosclerosis. Quantitative methods of evaluation. New York: Springer-Verlag, 1983:265-82.

23 Freedman DS, Gruchow HG, Anderson AJ, Rimm AA, Barboriak JJ. Relation of triglyceride levels to coronary artery disease: The Milwaukee Cardiovascular Data Registry. Am J Epidemiol 1988;127:1118-30.

24 Rowe GG, Thomsen JH, Sternlund RR, McKenna DH, Sialer S, Corliss RJ. A study of hemodynamics and coronary blood flow in man with coronary artery disease. Circulation 1969;39:139-48.

25 Block WD, Jarrett KJ Jr, Levine JB. Use of a single color reagent to improve the automated determination of serum total cholesterol. In: Skeggs LT Jr, ed. Automation in analytical chemistry. Technicon symposia 1965. New York: Mediad, 1966:345-7.

26 Kessler G, Lederer H. Fluorometric measurement of triglycerides. In: Skeggs LT Jr, ed. Automation in analytical chemistry. Technicon symposia 1965. New York: Mediad, 1966:341-4.

27 Manual of Laboratory Operation, Lipid Research
Clinics Program. Vol. 1. Bethesda, Md: National Institutes of Health, 1974; DHEW publication no. (NIH) 75-628.

28 Tretli S, Land-Larsen PG, Foss OP. Reliability of questionnaire information of cardiovascular disease and diabetes: Cardiovascular Disease Study in Finnmark county. J Epidemiol Community Health 1982;36:269-73.

29 Åberg H, Lithell H, Selinus I, Hedstrand H. Serum triglycerides are a risk factor for myocardial infarction but not for angina pectoris. Results from a 10-year follow-up of Uppsala Primary Preventive Study. Atherosclerosis 1985;54:89-97.

30 Kleinbaum DG, Kupper LL, Morgenstern H. Epidemiologic research. Principles and quantitative methods. Belmont, Ca: Wadsworth, 1982:331-51.

31 Kleinman JC, Feldman JJ, Monk MA. Trends in smoking and ischemic heart disease mortality. In: Havlik RJ, Feinleib $M$, eds. Proceedings of the conference on the decline in coronary heart disease mortality. Bethesda, Md: National Institutes of Health, 1979 (NIH publication no. 79-1610): 195-211.

32 Schlesselman JJ. Case-control studies. New York: Oxford University Press, 1982:241-4.

33 Rosenberg L, Kaufman DW, Helmrich SP, Shapiro S. The risk of myocardial infarction after quitting smoking in men under 55 years of age. $N$ Engl J Med 1985;313:1511-4.

34 McGill HC Jr. The cardiovascular pathology of smoking. Am Heart J 1988;118:250-7.

35 Wilhelmsson C, Vedin JA, Elmfeldt D, Tibblin G, Wilhelmsen L. Smoking and myocardial infarction. Lancet 1975; i:415-20.

36 Vlietstra RE, Kronmal RA, Oberman A, Frye RL, Killip T III. Effect of cigarette smoking on survival of patients with angiographically documented coronary artery disease. Report from the CASS Registry. JAMA 1986;255:1023-7.

37 Barry J, Mead K, Nabel EG, et al. Effect of smoking on the activity of ischemic heart disease. JAMA 1989; 261:398-402.

38 Fitzgerald GA, Oates JA, Nowak J. Cigarette smoking and hemostatic function. Am Heart $J$ 1988;115: 267-71.

39 Fried LP, Moore RD, Pearson TA. Long-term effects of cigarette smoking and moderate alcohol consumption on coronary artery diameter. Mechanisms of coronary artery disease independent of atherosclerosis or thrombosis? Am Heart J 1986;80:37-44.

40 Kuller L, Meilahn E, Ockene J. Smoking and coronary heart disease. In: Connor WE, Bristrow JD, eds. Coronary heart disease: prevention, complications, and treatment. Philadelphia: JB Lippincott, 1985:65-84. 